\title{
Responsibility of NSM FRP Bars in Shear Fortifying of Strengthened R.C. Beams
}

\section{Khaled Fawzy*}

Department of Structural Engineering, Zagazig University, Egypt

\begin{abstract}
Several R.C. (reinforced concrete) beams research have been surveyed in the shear area using fiber-reinforced polymer (FRP) composites and ended in collapse in the shear due to the separation of the FRP. The NSM method utilizing fiber fortified polymer (FRP) bars is currently an entrenched method for the reinforced concrete strengthening structures. The main proposal of this search is to look into experimentally for strengthening shear behavior with RC NSM carbon fiber reinforced polymer (CFRP) bars and exhibit the numerical outcomes for strengthened beams in shear with various FRP types; carbon fiber bar (CFRP), aramid fiber bar (AFRP), and glass fiber bar (GFRP) in shear. Three-dimensional beam models using finite element method are formed with software ANSYS-2013 to study the behavior of FRP in strengthening. Finally, a simply proposed equation is produced to estimate the shear strengthening capacity. The proposed equation affirms the exactness and viability of the experimental numerical result.
\end{abstract}

Keywords: Shear strenthening; FRP contribution; Near-surface mounted; FRP property

\section{Introduction}

Strengthening and healing of concrete structures have been among the most considerable challenges in structure engineering. Furthermore, the remedy price in supreme cases is far less than the replacement cost and thus reducing service interruption time $[1,2]$. Externally bonded reinforcing (EBR) procedure using FRP laminates has been used for enhanced the shear R.C. beams capacity [1,3-5]. The research has discovered that this technique cannot employ the full FRP tensile strength materials, due to their early debonding. Furthermore, EBR reinforcements could be highly prone to harm from collision, fire, and temperature dissimilarity, ultraviolet rays, and moisture absorption [6].

In an effort at overcoming these drawbacks, a strengthening technique designated by near surface mounted (NSM) was projected, where FRP rods are fixed into opened slice channel on the surface of concrete [7]. More recently, the (NSM) FRP has become a good-looking method for strengthening R.C. members, thus growing shear strength. The advantages of FRP compared to steel as NSM reinforcement are correct resistance to etching, with plainness and velocity of setting up due to its whippersnapper, jackanapes, and a lower groove size due to the higher ductile robustness and good consumption resistance of FRP.

Compared to on the surface bonded FRP reinforcement, the NSM system has a several advantages as indicated elsewhere [8,9]. The NSM procedure does not requisite wide surface preparation work, and after groove cutting, requires smallest putting in place time compared to externally bonded FRP laminates; the NSM reinforcement is sheltered by the concrete cover and so are less unprotected to unintentional impact and damage, fire, and harm; this characteristic makes this technology particularly fitting for the strengthing and repairing of negative moment regions of beams and slabs; the NSM reinforcement is fewer prone to debonding from the concrete substrate; the geometry shape of a strengthened structure with NSM are almost unchanged.

Many studies on using of NSM FRP for strengthening of R.C. beams in shear as well as flexural have been published [10-15]. De-Lorenzis et al. [15] studied the FRP rods characterizations as near-surface mounted reinforcement. Results show that the shear strength is enhanced.

Pongsak, Borvorn and Raktipong [13] examined shear fortifying of R.C. beams with internal stirrups by utilizing NSM FRP technique. The tested parameters are FRP type's rod, and FRP rods slope and its spacing. For specimens with FRP slope of 45 degrees and spacing 300 $\mathrm{mm}$ in both cases of AFRP and CFRP, the load capacity was close to specimens with angle 90 degree and spacing of $150 \mathrm{~mm}$. Changing the slope of rod to 45 degrees (perpendicular to shear cracks) while reducing a FRP rods number is efficient in the NSM FRP procedure because the total effective length of NSM FRP rods is increased, and the influence of each FRP rod to the shear strength can be consequently increased.

Using NSM FRP rods, the shear capacity is improved for Beam [15] Changing the rods spacing, strengthening form, and the rods anchorage, with existence internal reinforcement shear for examining shear tests.

De-Lorenzis et al. [15] increased flexural strength by $44 \%$, utilizing FRP as a near surface mounted for strengthening in shear and flexural. NSM bars have become a gorgeous solution due to their non-corrosive properties and the capability of tailoring the bar stiffness to the needs of the application [8].

The fundamental target of this research is to predict a equation for anticipating the shear beam capacity for using shear NSM carbon fiber reinforced polymer (CFRP) bars technique and present a numerical study investigation of the performance of strengthened beams with Three types of FRP; carbon fiber bar (CFRP), aramid fiber bar (AFRP), and glass fiber bar (GFRP) in shear.

\section{Experimental Work}

\section{Materials properties}

The materials used in the specimens for manufacture were a fine aggregate (sand), coarse aggregate (dolomite), cement, water, steel reinforcement, and CFRP bars for strengthening. The concrete compressive strength was designed to be $25 \mathrm{~N} / \mathrm{mm}^{2}$. Top and bottom reinforcement steel of the tested beams having tensile steel of (10 and 16 $\mathrm{mm}$ ) diameter with a yield strength of $360 \mathrm{~N} / \mathrm{mm}^{2}$ and ultimate strength of $520 \mathrm{~N} / \mathrm{mm}^{2}$ respectively were used. Mild steel of $6 \mathrm{~mm}$ diameter with yielding strength of $240 \mathrm{~N} / \mathrm{mm}^{2}$ and ultimate strength of $350 \mathrm{~N} / \mathrm{mm}^{2}$ had been used as internal shear reinforcement (stirrups). Sika (CFRP)

*Corresponding author: Khaled Fawzy, Department of Structural Engineering Zagazig University, Shaibet an Nakareyah, Markaz El-Zakazik, Ash Sharqia Governorate 44519, Egypt, Tel: +20552364612; E-mail: khaled_lashen1@yahoo.com

Received October 16, 2017; Accepted February 01, 2018; Published February 06, 2018

Citation: Fawzy K (2018) Responsibility of NSM FRP Bars in Shear Fortifying of Strengthened R.C. Beams. J Civil Environ Eng 8: 298. doi: 10.4172/2165784 X.1000298

Copyright: () 2018 Fawzy K. This is an open-access article distributed under the terms of the Creative Commons Attribution License, which permits unrestricted use, distribution, and reproduction in any medium, provided the original author and source are credited. 


\begin{tabular}{|c|c|c|c|c|}
\hline Bar type & $\begin{array}{c}\text { Bar diameter } \\
(\mathbf{m m})\end{array}$ & $\begin{array}{c}\text { Modules of } \\
\text { elasticity (GPa) }\end{array}$ & $\begin{array}{c}\text { Tensile } \\
\text { Strength (MPa) }\end{array}$ & $\begin{array}{c}\text { Ultimate strain } \\
\%\end{array}$ \\
\hline CFRP & 10 & 130 & 2300 & $1.6 \pm 0.05$ \\
\hline GFRP & 10 & 42 & $749 \pm 27$ & $1.80 \pm 0.04$ \\
\hline AFRP & 10 & 70 & $1300 \pm 15$ & $1.90 \pm 0.05$ \\
\hline
\end{tabular}

Table 1: Property of FRP bars.

\begin{tabular}{|c|c|}
\hline \multicolumn{2}{|c|}{ Technical data } \\
\hline Density & $1.77 \mathrm{Kg} / \mathrm{l}$ \\
\hline Thixotropy & $20 \mathrm{~mm}$ film thickness $\left(\mathrm{at}+35^{\circ} \mathrm{C}\right)$ \\
\hline Sag Flow & $3-5 \mathrm{~mm}$ \\
\hline Squeezability at $15 \mathrm{~kg}$ & $4000 \mathrm{~mm}^{2}\left(\right.$ at $\left.+15^{\circ} \mathrm{C}\right)$ \\
\hline shrinkage & $0.04 \%$ \\
\hline Brittle Temperature & $62^{\circ} \mathrm{C}$ \\
\hline Modulus of Elasticity & $12800 \mathrm{~N} / \mathrm{mm}^{2}$ \\
\hline coefficient of thermal expansion & $9^{*} 10^{-5}$ per $^{\circ} \mathrm{C}\left(-10^{\circ} \mathrm{C}\right.$ to $\left.+40^{\circ} \mathrm{C}\right)$ \\
\hline Tensile bending strength & Concrete failure $\left(4 \mathrm{~N} / \mathrm{mm}^{2}\right)$ \\
\hline shear strength & Concrete failure $\left(15 \mathrm{~N} / \mathrm{mm}^{2}\right)$ \\
\hline
\end{tabular}

Table 2: Technical data, properties of Epoxy adhesive by the manufacturer.
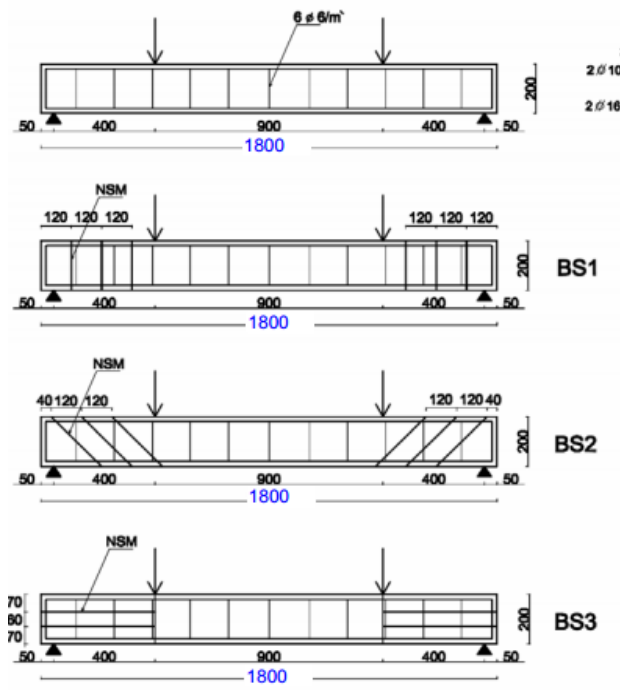

Figure 1: Beams specimens (unit: $\mathrm{mm}$ ).

\begin{tabular}{|c|c|c|c|c|}
\hline Beam & $\begin{array}{c}\text { Shear } \\
\text { strengthening } \\
\text { system }\end{array}$ & $\begin{array}{c}\text { Spacing of steel } \\
\text { stirrup(mm) }\end{array}$ & $\begin{array}{c}\text { Spacing of NSM } \\
\text { bars (mm) }\end{array}$ & $\begin{array}{c}\text { Slope of NSM } \\
\text { FRP (degree) }\end{array}$ \\
\hline BS0 & Steel Stirrups & 150 & - & - \\
\hline BS1 & $\begin{array}{c}\text { Steel Stirrups and } \\
\text { CFRP }\end{array}$ & 150 & 120 & $90^{\circ}$ \\
\hline BS2 & $\begin{array}{c}\text { Steel Stirrups and } \\
\text { CFRP }\end{array}$ & 150 & 120 & $45^{\circ}$ \\
\hline BS3 & $\begin{array}{c}\text { Steel Stirrups and } \\
\text { CFRP }\end{array}$ & 150 & 60 & $0^{\circ}$ \\
\hline
\end{tabular}

Table 3: Test specimens.

bars with a circular cross section $10.00 \mathrm{~mm}$ are used to improve, the shear capacity of beams. The technical data and mechanical properties of FRP were presented in Table 1. An epoxy adhesive type Sikadur -30 produced by Sika Company was used in this research. Technical data of epoxy adhesive type Sikadur -30 are exposed in Table 2.

\section{Test specimens}

Four tested beams having cross-section $120 \times 200 \mathrm{~mm}$ and 1800 $\mathrm{mm}$ length were cast. The reinforcement consisted of two $16 \mathrm{~mm}$ (bottom) and two $10 \mathrm{~mm}$ (top) diameter with yielding stress $360 \mathrm{MP}$. The web reinforcement consisted of closed stirrups with $6 \mathrm{~mm}$ diameter having yielding stress $240 \mathrm{MP}$ and arranged with constant spacing 150 $\mathrm{mm}$ along the beam length as exposed in Figure 1.

One beam namely BS0 was tested as control beam to obtain the unstrengthened beam capacity. Three beams were fortified with NSM FRP bars namely BS1 with vertical bars, BS2 with inclined bar with angle $45^{\circ}$, and BS3 with horizontal bars as shown in Table 3. Vertical displacement transducers (LVDT) were used in the mid-span to measure the machine displacement increment while strain gauges were mounting on the NSM CFRP bars.

\section{Strengthening procedure}

Following the 28-day curing period, the tested beams were placed to their sides to put and paste the NSM CFRP bars in the grooves by the epoxy adhesive, the measurement of the grooves was taken at 1.5 times the diameter of CFRP bar. A brush was used to remove any particles or impurities in the grooves. To introduce the NSM CFRP bars, the depressions were filled marginally more than mostly full, and after that the bars were pushed into the sections, so they were adequately encompassed by epoxy. Abundance epoxy was then scratched off utilizing putty blades until the point that the epoxy was flush with the sides of the bar. For bonding, the epoxy was allowed to be seated for 36 hours. Also, the strain gauges were added to the CFRP bars surface for measuring the strain occurred in the bars (Figure 2).

\section{Concrete compression test}

Concrete cubes with $15 \times 15 \times 15 \mathrm{~cm}$ side lengths were used to define the compressive strength $\left(\mathrm{f}_{\mathrm{cu}}\right)$. Six cubes were taken and tested at ages 7 and 28 days by using $2000 \mathrm{kN}$ compression test machine. The results after 7 days were $19.6,19.8$, and $21.3 \mathrm{~N} / \mathrm{mm}^{2}$ and after 28 days were $28,28.2$, and $29 \mathrm{~N} / \mathrm{mm}^{2}$.

\section{Nonlinear Finite Element Analysis}

ANSYS- 2013 finite element program is used for analysis. The concrete damaged plasticity model in ANSYS provides a general facility for modeling concrete in all types of structures using concepts of isotropic damaged elasticity. The SOLID 65 and LINK180 elements were used to model the concrete and steel, CFRP tendons respectively. Figure 3 shows the loads, supports and boundary conditions and Figure 4 shows all beam reinforcement internal and external.

\section{Parametric Study}

In this numerical study all models were rectangular $(120 \mathrm{~mm} \times 200$

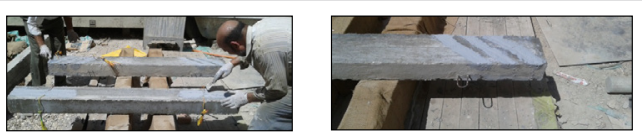

Figure 2: Beams specimens with NSM bars Installed.

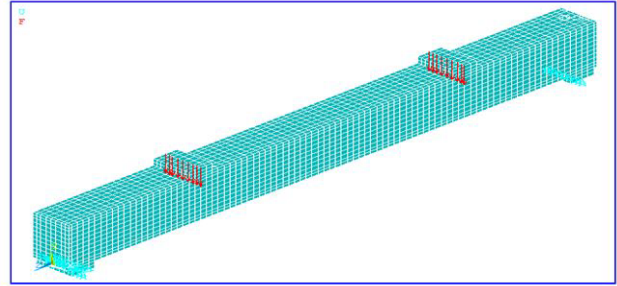

Figure 3: Loads, supports and boundary conditions. 
$\mathrm{mm}$ ) with length $1800 \mathrm{~mm}$ as shown in Figure 1. One control beam (BS0) and 12 specimens strengthened in shear with different types of fiber carbon (CFRP), aramid fiber (AFRP) and glass fiber (GFRP). The models include six specimens strengthened vertically with CFRP, AFRP and GFRP bars with diameter $10 \mathrm{~mm}$ and with different spacing 120 $\mathrm{mm}$ (three FRP bars each side) and $60 \mathrm{~mm}$ (five FRP bars each side). The other models include six specimens strengthened horizontally with CFRP, AFRP and GFRP bars with diameter $10 \mathrm{~mm}$ and with different spacing $60 \mathrm{~mm}$ (two FRP bars each side) and $50 \mathrm{~mm}$ (three FRP bars each side), Table 4 shows the study model details. The properties of the FRP reinforcing bars and epoxy adhesive used in this study are listed before in Tables 1 and 2 .

\section{Results and Discussion}

\section{Cracking behavior}

The pattern failure of all four beams was in shear with almost diagonal shear cracks and the failure pictures shown are in Figure 5. The control specimen (BS0) was designed to fail in shear, so the first crack was found at a shear force of $56 \mathrm{kN}$ near the half distance the shear span left at the beam bottom. The crack extended to the upper beam nearly to the position load with increasing the loading, a second shear crack appeared with horizontal crack (bond-slip crack) along the tension reinforcement between the first crack and the left support, and

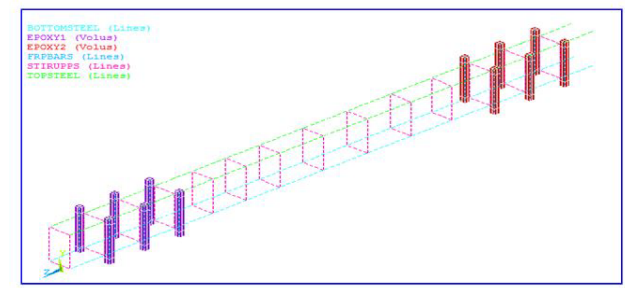

Figure 4: Internal and external reinforcement of the model.

\begin{tabular}{|c|c|c|c|c|}
\hline Model & $\begin{array}{c}\text { Shear strengthening } \\
\text { system }\end{array}$ & $\begin{array}{c}\text { Spacing } \\
\text { of steel } \\
\text { stirrup(mm) }\end{array}$ & $\begin{array}{c}\text { Spacing of } \\
\text { NSM bars } \\
(\mathrm{mm})\end{array}$ & $\begin{array}{r}\text { Slope of } \\
\text { NSM FRP } \\
\text { (degree) }\end{array}$ \\
\hline BSO & Steel Stirrups & 150 & - & - \\
\hline BS1-C-120 & $\begin{array}{c}\text { Steel Stirrups and CFRP } \\
\text { bars }\end{array}$ & 150 & 120 & $90^{\circ}$ \\
\hline BS1-A-120 & $\begin{array}{c}\text { Steel Stirrups and AFRP } \\
\text { bars }\end{array}$ & 150 & 120 & $90^{\circ}$ \\
\hline BS1-G-120 & $\begin{array}{c}\text { Steel Stirrups and GFRP } \\
\text { bars }\end{array}$ & 150 & 120 & $90^{\circ}$ \\
\hline BS1-C-60 & $\begin{array}{c}\text { Steel Stirrups and CFRP } \\
\text { bars }\end{array}$ & 150 & 60 & $90^{\circ}$ \\
\hline BS1-A-60 & $\begin{array}{l}\text { Steel Stirrups and AFRP } \\
\text { bars }\end{array}$ & 150 & 60 & $90^{\circ}$ \\
\hline BS1-G-60 & $\begin{array}{c}\text { Steel Stirrups and GFRP } \\
\text { bars }\end{array}$ & 150 & 60 & $90^{\circ}$ \\
\hline BS3-C-60 & $\begin{array}{c}\text { Steel Stirrups and CFRP } \\
\text { bars }\end{array}$ & 150 & 60 & $0^{\circ}$ \\
\hline BS3-A-60 & $\begin{array}{l}\text { Steel Stirrups and AFRP } \\
\text { bars }\end{array}$ & 150 & 60 & $0^{\circ}$ \\
\hline BS3-G-60 & $\begin{array}{c}\text { Steel Stirrups and GFRP } \\
\text { bars }\end{array}$ & 150 & 60 & $0^{\circ}$ \\
\hline BS3-C-50 & $\begin{array}{c}\text { Steel Stirrups and CFRP } \\
\text { bars }\end{array}$ & 150 & 50 & $0^{\circ}$ \\
\hline BS3-A-50 & $\begin{array}{l}\text { Steel Stirrups and AFRP } \\
\text { bars }\end{array}$ & 150 & 50 & $0^{\circ}$ \\
\hline BS3-G-50 & $\begin{array}{c}\text { Steel Stirrups and GFRP } \\
\text { bars }\end{array}$ & 150 & 50 & $0^{\circ}$ \\
\hline
\end{tabular}

Table 4: Study model details.

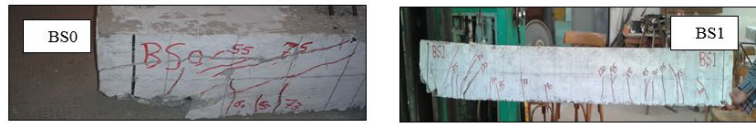

Figure 5: Mode of failure of specimen beams.

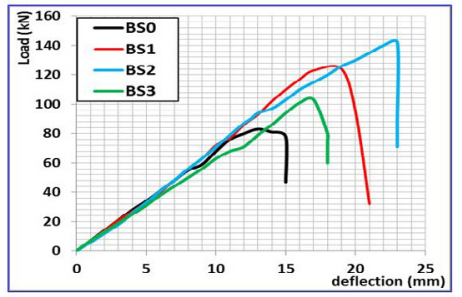

Figure 6: Load-deflection curves for all tested beams.

shear tension failure happened at a shear force $83 \mathrm{kN}$. For strengthened (BS1), (BS2), and (BS3), the NSM technique inhibited the propagation of shear diagonal cracks and prevented the slip bond failure, the cracks were observed as a shear cracks at a shear force 74,96 , and $70 \mathrm{kN}$., respectively. The cracks extended with increasing the applied load and more cracking occurred on the concrete between adjacent epoxy-filled grooves, a shear tension failure happened. No debonding or fracture of CFRP bars was remarked at failure. Therefore, NSM procedure of attaching FRP bars to reinforce concrete members in shear seems more successful rivaled to the externally bonded cases.

\section{Load and deflection}

The deflection was measured at the mid beam span. Loads and their corresponding deflection for the tested specimens are shown in Figure 6. The main outcome is presented in Table 5, which shows the crack, ultimate load, the corresponding middle span deflection values of tested specimens, initial stiffness, and the extreme strain. $\mathrm{P}_{\mathrm{u}-\mathrm{C}}$ is the ultimate load of a control beam (BS0), $\mathrm{P}_{\mathrm{u}-\mathrm{Str}}$ is the ultimate load of strengthened beams (Bsi), and $\Delta_{\mathrm{u}}$ represents the deflection of the beam at ultimate load.

It is observed that use of CFRP allowed more deflection before failure in addition to increasing the load capacity. The deflection at the failure of the strengthened RC beams is approximately increased by $46 \%, 77 \%$, and $31 \%$ for BS1, BS2, and BS3 respectively than the control beam BSO. The strengthening of the beam using NSM CFRP bars with angel $45^{\circ}$ at the two sides of the beam give the best results. The ratios of $\mathrm{P}_{\mathrm{u}-\mathrm{Str}} / \mathrm{P}_{\mathrm{u}-\mathrm{c}}$ were determined for assessing the efficacy of the strengthening techniques, in terms of increasing the beam load carrying capacity, the increase in the load capacity was $49 \%, 71 \%$, and $24 \%$ respectively than the control beam BS0. Therefore, NSM procedure of attaching FRP bars in shear seems reasonably effectual and may be considered as one of the efficient methods for strengthening members in shear.

It can be noted that all the strengthened specimens with different orientation have in the region of the same initial stiffness before cracks (differences within 9\%).

The load versus CFRP strain relationship for the three model beams is exposed in Figure 7. The maximum failure loads for BS1, BS2, and BS3 were recorded as 124, 142 and $103 \mathrm{kN}$, with a corresponding maximum strain of $1,443,1,862$, and 1,099 micro-strain, respectively, as shown in Table 5. Once the concrete in the shear province cracked diagonally, the shear force was transferred to the CFRP bars, and a rapid increase in strain in the CFRP bars was observed. 
Citation: Fawzy K (2018) Responsibility of NSM FRP Bars in Shear Fortifying of Strengthened R.C. Beams. J Civil Environ Eng 8: 298. doi: 10.4172/2165-784X.1000298

\section{Modeling confirmation}

To verify the modeling constructed using the program ANSYS. Three models BS0, BS1, and BS3, which are identical to those tested experimentally are prepared and constructed by the program, their results are compared to those obtained experimentally for validation of the modeling results. Table 3 and Figure 1 show the dimensions and the reinforcement details for the tested beams.

Deflections and load capacities of experimental models adjacent to finite element models at ultimate Load with differences in percentage were shown in Table 6 and Figure 8. It is seen that the FEM models provided good predictions against the experimental data, including maximum errors of $5.08 \%$, for the ultimate loads and $17.77 \%$ for the great deflection.

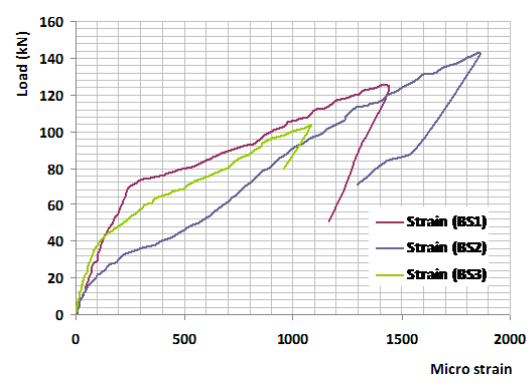

Figure 7: Load-strain curves for testing beams.

\begin{tabular}{|c|c|c|c|c|c|c|c|c|}
\hline Beam & $\begin{array}{c}\mathbf{P}_{\text {cr }} \\
\mathbf{~ N o . ~}\end{array}$ & $\begin{array}{c}\boldsymbol{\Delta}_{\text {cr }} \\
\mathbf{( \mathbf { m m } )}\end{array}$ & $\begin{array}{c}\mathbf{P u} \\
\mathbf{( K N )}\end{array}$ & $\begin{array}{c}\mathbf{P}_{\text {u-str }} \\
\mathbf{P}_{\text {u-c }}\end{array}$ & $\begin{array}{c}\mathbf{\Delta}_{\mathbf{u}} \\
\mathbf{( m m})\end{array}$ & $\begin{array}{c}\boldsymbol{\Delta}_{\text {u-Strl }} \\
\mathbf{\Delta}_{\text {u-c }}\end{array}$ & $\mathbf{K}_{\mathbf{i}}=\mathbf{P}_{\text {crl }} \boldsymbol{\Delta}_{\text {cr }}$ & $\begin{array}{c}\text { Max. Strain } \\
\mathbf{X} \mathbf{1 0}^{-6}\end{array}$ \\
\hline BS0 & 56 & 8.5 & 83 & 1 & 13 & 1 & 6.59 & - \\
\hline BS1 & 74 & 10.4 & 124 & 1.49 & 19 & 1.46 & 7.12 & 1443 \\
\hline BS2 & 96 & 13.3 & 142 & 1.71 & 23 & 1.77 & 7.22 & 1862 \\
\hline BS3 & 70 & 11.3 & 103 & 1.24 & 17 & 1.31 & 6.31 & 1099 \\
\hline
\end{tabular}

Table 5: Main results obtained in the tested beams.

\begin{tabular}{|c|c|c|c|c|c|c|}
\hline \multicolumn{2}{|c|}{$\begin{array}{c}\text { Difference } \\
\text { percentage }\end{array}$} & \multicolumn{2}{c|}{$\begin{array}{c}\text { Finite element } \\
\text { results }\end{array}$} & \multicolumn{2}{c|}{ Experimental results } & Beam \\
\hline $\begin{array}{c}\text { Deflection } \\
\%\end{array}$ & Load \% & $\begin{array}{c}\text { Maximum } \\
\text { deflection } \\
(\mathbf{m m})\end{array}$ & $\begin{array}{c}\text { Ultimate } \\
\text { Load (kN) }\end{array}$ & $\begin{array}{c}\text { Maximum } \\
\text { deflection } \\
(\mathbf{m m})\end{array}$ & $\begin{array}{c}\text { Ultimate } \\
\text { Load (kN) }\end{array}$ & No. \\
\hline $17.77 \%$ & $3.75 \%$ & 15.31 & 80 & 13 & 83 & BS0 \\
\hline $0.68 \%$ & $5.08 \%$ & 19.13 & 118 & 19 & 124.0 .0 & BS1 \\
\hline $11.06 \%$ & $0.97 \%$ & 18.88 & 104 & 17 & 103 & BS3 \\
\hline
\end{tabular}

Table 6: Deflections and load capacities of experimental versus. finite element models.

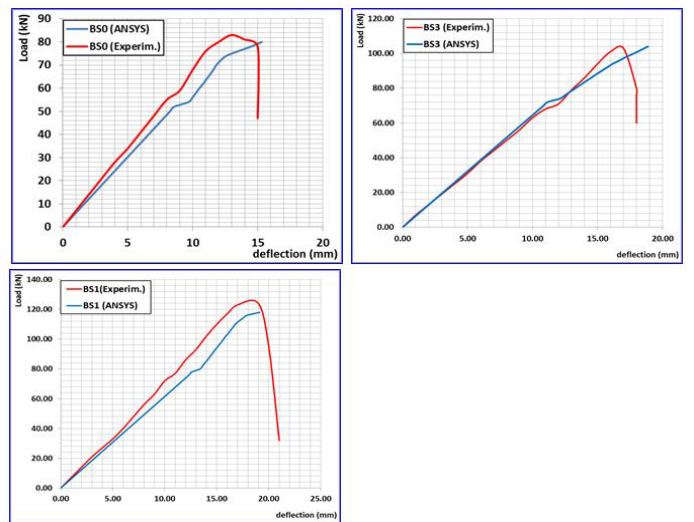

Figure 8: Load deformation responses for BS0, BS1, and BS3.

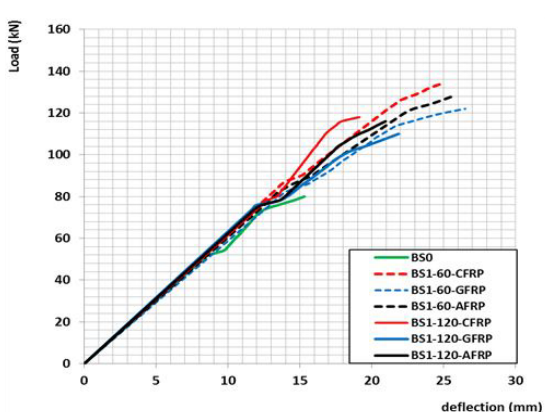

Figure 9: Load deformation responses for BS0, BS1 group.

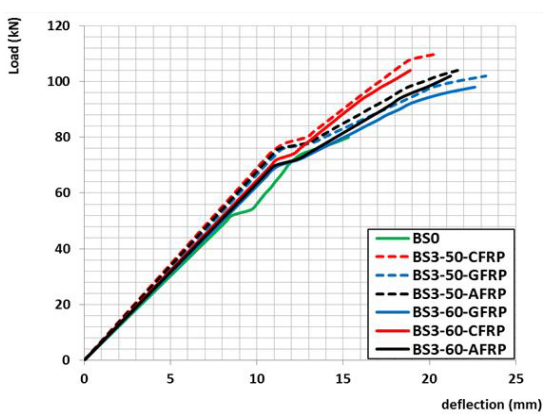

Figure 10: Load deformation responses for BS0, BS3 group.

\begin{tabular}{|c|c|c|c|c|c|c|c|}
\hline Code & $\mathbf{P}_{\mathrm{cr}}(\mathbf{K N})$ & $\boldsymbol{\Delta}_{\mathrm{cr}}(\mathbf{m m})$ & $\mathbf{P u}(\mathbf{K N})$ & $\boldsymbol{\Delta}_{\mathrm{u}}(\mathbf{m m})$ & $\begin{array}{c}\mathbf{K}_{\mathbf{i}}=\mathbf{P}_{\mathrm{cr} r} \\
\mathbf{\Delta}_{\mathrm{cr}}\end{array}$ & $\mathbf{P}_{\mathrm{u}-\mathrm{Strl}} \mathbf{P}_{\mathrm{u}-\mathrm{c}}$ & $\boldsymbol{\Delta}_{\mathrm{u}-\mathrm{Str} /} \mathbf{\Delta}_{\mathrm{u}-\mathrm{c}}$ \\
\hline BS0 & 54 & 9.66 & 80 & 15.31 & 5.59 & 1 & 1 \\
\hline BS1-C-120 & 80 & 13.4 & 118 & 19.13 & 5.97 & 1.48 & 1.25 \\
\hline BS1-A-120 & 78 & 13.44 & 116 & 20.95 & 5.8 & 1.45 & 1.37 \\
\hline BS1-G-120 & 77 & 13.51 & 110 & 21.86 & 5.69 & 1.38 & 1.43 \\
\hline BS1-C-60 & 88 & 14.26 & 134 & 24.85 & 6.17 & 1.68 & 1.62 \\
\hline BS1-A-60 & 86 & 14.5 & 126 & 25.61 & 5.93 & 1.58 & 1.67 \\
\hline BS1-G-60 & 84 & 14.65 & 122 & 26.39 & 5.73 & 1.53 & 1.72 \\
\hline BS3-C-60 & 74 & 12.1 & 104 & 18.88 & 6.12 & 1.3 & 1.23 \\
\hline BS3-A-60 & 72 & 12.3 & 102 & 21.22 & 5.85 & 1.28 & 1.39 \\
\hline BS3-G-60 & 72 & 12.43 & 98 & 22.62 & 5.79 & 1.23 & 1.48 \\
\hline BS3-C-50 & 80 & 12.87 & 110 & 20.49 & 6.22 & 1.38 & 1.34 \\
\hline BS3-A-50 & 78 & 12.95 & 104 & 21.62 & 6.02 & 1.3 & 1.41 \\
\hline BS3-G-50 & 78 & 13.19 & 102 & 23.26 & 5.91 & 1.28 & 1.52 \\
\hline
\end{tabular}

Table 7: Main results obtained in the tested beams.

\section{Numerical analysis results}

Figures 9 and 10 represent the relationship between the load and their displacement at mid-span of the tested beams. The main results are presented in Table 7 .

Figure 9 shows the mid-span deflection at an ultimate load of all beams BS0 and a group of BS1 with vertical strengthening. Comparing the strengthening beams to the control beam (BSO), the strengthening beams with carbon, aramid, and glass attained an rise in the maximum load, $48 \%, 45 \%$, and $38 \%$ respectively and deformation capacity $25 \%$, $37 \%$, and $43 \%$ respectively, for spacing between NSM FRP bars equals $120 \mathrm{~mm}$. As the spacing between NSM FRP bars decreases $(60 \mathrm{~mm})$, the load capacity increase $68 \%, 58 \%$, and $53 \%$ and the deformation capacity by $62 \%, 67 \%$, and $72 \%$ respectively.

Figure 10 shows the mid-span deflection at an ultimate load of all beams BS0 and a group of BS3 with FRP horizontal strengthening. The same observation is founded on curves displayed in Figure 9 is obtained 
in Figure 10. Using NSM FRP bars with vertical distance $60 \mathrm{~mm}$ lead to increase load capacity by $30 \%, 28 \%$, and $23 \%$ in carbon, aramid, and glass specimens than the control beam and in deformation capacity by $23 \%, 39 \%$, and $48 \%$ in carbon, respectively, while using NSM FRP bars with vertical distance $50 \mathrm{~mm}$ lead to increase load capacity by $38 \%$, $30 \%$, and $28 \%$ respectively and in deformation capacity by $34 \%, 41 \%$, and $52 \%$ respectively.

The results indicated that as the space between NSM FRP decreases, the early stiffness increases slightly for all specimens. For a group of BS1 with vertical strengthening, using distance $60 \mathrm{~mm}$ lead to a little increase of initial stiffness by $3 \%, 2 \%$, and $1 \%$ for carbon, aramid, and glass specimens respectively than specimens which using distance 120 $\mathrm{mm}$. For a group of BS3 with horizontal strengthening, using distance $50 \mathrm{~mm}$ lead to a little increase of initial stiffness by $2 \%, 3 \%$, and $2 \%$ in carbon, aramid, and glass specimens respectively than specimens which using distance $60 \mathrm{~mm}$.

\section{Assessment the Performance of Analytical Formulations}

The nominal shear capability of the member having FRP shear strengthening using NSM bars is similar to that used in ACI 318-05 [16] for the externally bonded FRP laminate

$$
\varnothing V=\varnothing\left(V_{c}+V_{s}+\psi V_{f}\right)
$$

Where $\mathrm{V}_{\mathrm{c}}$ and $\mathrm{V}_{\mathrm{s}}$ are computed based on Equations of ACI 318-05. The reduction value of $\varnothing$ is determined to be 0.85 and an additional reduction factor $\psi=0.85$ is applied to the influence of NSM FRP to the member shear strength for side bonding depended on a reliability study of existing experimental data. The involvement nominal shear strength by concrete and steel bars can be determined by the following Equations 2, and 3 respectively.

$$
\begin{aligned}
& V_{c=}\left(\sqrt{ } f_{c} / 6\right) b_{w} d \\
& V_{s=} A_{v} f_{y} d / s
\end{aligned}
$$

Where $f_{c}=$ specified compressive strength of concrete (MPa), $\mathrm{b}_{\mathrm{w}}=$ beam web width $(\mathrm{mm}), \mathrm{d}=$ distance from maximum compression fiber to centroid tension reinforcement $(\mathrm{mm}), \mathrm{A}_{\mathrm{v}}=$ shear steel area $\left(\mathrm{mm}^{2}\right), \mathrm{f}_{\mathrm{y}}=$ tensile yield of shear steel $(\mathrm{MPa}), \mathrm{s}=$ spacing of shear steel area $(\mathrm{mm})$.

Several parameters influence the involvement NSM FRP to the shear $\left(V_{\mathrm{f}}\right)$, such as quality of the bond, FRP type, groove size, and quality of the substrate material. When computing $V_{\rho}$ two strain limits need to be taken into account [11], namely: strain from bond-controlled failure, and maximum strain sill of 0.004 . The latter is suggested to keep up the shear integrity of the concrete [17], and to evade large shear cracks that could cooperation the aggregate interlock mechanism.

Bond properties between FRP and concrete are like to that of steel reinforcement and depend on FRP type, elastic modulus, surface deformation, and FRP bar shape [18-20]. For the strengthened R.C. beams with NSM CFRP rectangular bars, Hassan and Rizkalla [21] found that the improvement length is dependent on strip dimensions; groove size, concrete and adhesive properties, internal steel ratio, reinforcement configuration, and loading type. They suggested that the development length increases by increasing the internal ratio of steel reinforcement and decreases with the increase of either the compressive strength of concrete the groove dimension.

AKM Anwarul Islam [22] suggested a formula (Equation 4) to calculate the nominal shear strength provided by NSM CFRP bars $\left(V_{y}\right)$, depending on a limited experimental result and that Shear steel almost reached its ultimate strain before failure, whereas effective strains in the
CFRP bars are surrounded by a range of 30 to $35 \%$ of its ultimate strain before shear failure of the beams.

$$
\begin{gathered}
V_{y}=1 / 3\left(A_{f} f_{y f} d / S_{f}\right) \\
\mathrm{V}_{y=} A_{f} E_{f} \varepsilon_{e f} d / S_{f}
\end{gathered}
$$

$A_{f}=$ shear area of FRP $(\mathrm{mm} 2), A_{y f}=$ tensile strength FRP (MPa), $S_{f}=$ shear spacing of FRP $(\mathrm{mm}), \varepsilon_{e f}$ effective strain in Frp bars, $E_{f}=$ modulus of elasticity of FRP (MPa).

Equation 4 neglected the influence of the development length; groove dimension, concrete and adhesive properties, internal steel ratio, reinforcement configuration, and type of loading.

The Equation 5 is more accurate than Equation 4 and can be modified to take the effect orientation of strengthening FRP bars $(\alpha)$ with the longitudinal beam axis.

$$
V_{y=} A_{f} E_{f} \varepsilon_{e f} d(\sin \alpha+\cos \alpha) / S
$$

For $\alpha=0$, the equation (6) become

$V_{y}=A_{f} E_{f} \varepsilon_{e f}$

(Khalifa et al. [19] suggested a reduction factor on the ultimate strain for FRP sheet R.

$$
R=0.5622(\rho f E f)^{2}-1.2188(\rho f E f)+0.778 \leq 0.50
$$

The upper limit $\mathrm{R}$ of 0.50 has the effect of restrictive the strain in the FRP sheet to an order of $400 \mu \varepsilon$ to $500 \mu \varepsilon$. This limit is suggested to maintain the shear integrity of the concrete. At higher levels of strain, the shear crack widths will probable such that aggregate interlock would be lost, and the shear capacity of the concrete dramatically reduced [23]. The equation 8 is further modified based on the equation are only applicable when failure is governed by NSM FRP bars rupture not by FRP bars delamination and the FRP surface contact with three surfaces. Therefore, the following equation 9 is being proposed to calculate the reduction factor $R_{m}$ on the ultimate strain for NSM FRP bars.

$R_{m}=0.14056\left(\rho_{f} E_{f}\right)^{2}-0.3047\left(\rho_{f} E_{f}\right)+0.197 \leq 0.50$

Where $\rho_{f}=$ FRP shear reinforcement $=2 d_{f} / b_{w} S_{f}$

$E_{f}=$ tension modulus of elasticity of FRP (GPa).

$d_{f}=$ diameter of FRP bar.

The effective strain for use in equation 6 may be computed from equation 10.

$$
\varepsilon_{e f=} R_{m} \varepsilon_{u}
$$

\begin{tabular}{|c|c|c|c|c|c|c|}
\hline Beam & $\begin{array}{c}\varnothing \mathrm{V} 4 \\
\mathrm{kN}\end{array}$ & $\begin{array}{c}\varnothing \mathbf{V} 5 \\
\text { kN }\end{array}$ & $\begin{array}{c}\emptyset \mathrm{V} 6 \\
\text { kN }\end{array}$ & $\underset{\mathbf{k N p}}{\mathbf{v}_{\exp }}$ & $\begin{array}{c}\varnothing \mathrm{V} 11 \\
\mathrm{kN}\end{array}$ & \begin{tabular}{c}
$V e x p$ \\
\hdashline$V 11$
\end{tabular} \\
\hline Bso & 35.49 & 35.49 & 35.49 & 41.5 & 35.49 & 1.169 \\
\hline Bs1 & 91.77 & 60.3 & 60.3 & 62 & 65.35 & 0.9487 \\
\hline Bs2 & 115.95 & 60.4 & 84.6 & 71 & 79.45 & 0.894 \\
\hline Bs3 & 115.95 & 46.38 & 46.38 & 51.5 & 54.9 & 0.938 \\
\hline
\end{tabular}

The suggested a formula to calculate the nominal shear strength provided by NSM CFRP bars $\left(\mathrm{V}_{\mathrm{y}}\right)$ is

$$
V_{y}=A_{f} E_{f} R_{m} \varepsilon_{u} d(\sin \alpha+\cos \alpha) / S
$$

Table 8 presents the shear capacity according to numerical predictions and experimental results Bso, Bs1, Bs2, and Bs3.

Table 8: Comparison between strengthened beams using different equations (Equations 4-6) with proposed Equations 9 and11. 
The proposed design approach gives results realistically close to experimental values. Furthermore, all predictions are conservative.

\section{Conclusion}

Shear behavior of the control beams and the strengthened beams using FRP bars were investigated and the following conclusions are summarized:

1. Using of NSM FRP as strengthening in two sides of the beam improved the load-deflection response of the reinforced concrete beams and significantly increased the final load.

2. NSM FRP shear strengthening has a high potential to increase shear capacity of reinforced concrete beams ranging from $12 \%-35 \%$ compared to a control beam.

3. The strengthening of the beam using NSM CFRP bars with angel $45^{\circ}$ at the two sides of the beam give the best results, the shear capacity increased by $35 \%$ of control beam.

4. The decreasing distance between NSM FRP bars has a little effect on increasing the load capacity and the flexural initial stiffness.

5. The proportion of successful strain to extreme strain, $\mathrm{R}$, that is utilized as a diminishment factor on a definitive strain for CFRP sheet figured by Khalifa et al. [19] can be altered to produce the results of NSM CFRP bars fortifying.

6. The shear capacity of strengthening NSM CFRP bars of proposed equation give a good agreement with experimental results.

\section{References}

1. Tavakkolizadeh $M$ (2001) Strengthening and repair of steel $U$ concrete composite girders using CFRP laminates.

2. Hollaway MA, Raoof M (2001) Strengthening of Reinforced Concrete Structure. CRC press, USA.

3. Yang DS, Park SK, Neale KW (2009) Flexural behavior of reinforced concrete beams strengthened with prestressed carbon composites. Compos Struct 88:497-508.

4. Chen JF, Teng JG (2001) Anchorage strength models for FRP and steel plates bonded to concrete. J Struc Engineer 127:784-791.

5. De-Lorenzis L, Antonio N (2001) Shear strengthening of reinforced concrete beams with near surface mounted fiber reinforced polymer rods, $\mathrm{ACl}$ Struc $J$ 98:60-68.

6. Soudki K, Alkhrdaji T (2005) Guide for the design and construction of externally bonded FRP systems for strengthening concrete structures ( $\mathrm{ACl} 440.2 \mathrm{R}-02)$. Structures Congress.

7. Asplund SO (1949) Strengthening bridge slabs with grouted reinforcement American Concrete Institute 45: 397-406.
8. Parretti R, Nanni A (2004) Strengthening of RC members using near surface mounted FRP composites: Design overview. Adv Struct Eng 7:469-483.

9. De Lorenzis L, Teng JG (2007) Near surface mounted FRP reinforcement: An emerging technique for strengthening structures. Composites Part B 38:119143

10. Sharaky IA, Torres L, Sallam HEM (2015) Experimental and analytical investigation into the flexural performance of $R C$ beams with partially and fully bonded NSM FRP bars/strips. Compos Struct 122:113-126.

11. De-Lorenzis L, Nanni A (2001) Characterization of FRP rods as near surface mounted Reinforcement. J Compos Constr 5:114-121.

12. Sharaky IA, Torres L, Comas J, Barris C (2014) Flexural response of reinforced concrete (RC) beams strengthened with near surface mounted (NSM) fibre reinforced polymer (FRP) bars. Compos Struct 109:8-22.

13. Wiwatrojanagul P, Ayudhya BI, Sahamitmongkol R (2012) NSM FRP shea strengthening of RC beams with internal stirrups. Science Technol Asia 17:16-30.

14. Reda RM, Sharaky IA, Ghanem M, Seleem MH, Sallam HEM (2016) Flexura behavior of RC beams strengthened by NSM GFRP bars having different end conditions. Compos Struct 147: 131-142.

15. De Lorenzis L, Nanni A, La Tegola (2000) Flexural and shear strengthening of reinforced concrete structures with Near Surface Mounted FRP rods. Proceeding of the $4^{\text {th }}$ international Conference on Advanced Composites Materials in Bridges and Structures (ACMBS 2000), J.L. Humar and A.G Razagpur (eds), Canadian Society for Civil Engineering, Ottawa. pp. 521-528.

16. Khalifa A, Gold WJ, Nanni A, Aziz A (1998) Contribution of externally bonded FRP to shear capacity of RC flexural members. J Compos Constr 2:195-202.

17. ACl Committee (2008) Building Code Requirements for Structural Concrete (ACl 318-05) and Commentary (ACl 318R-05) American Concrete Institute.

18. Al-Zahrani MM, Nanni A, Al-Dulaijan SU, Bakis CE (1996) Bond of FRP to concrete for bars with axisymmetric deformations. Proceedings of the Second International Conference on Advanced Composite Materials in Bridges and Structures (ACMBS-II), Montreal, Canada. pp. 853-860.

19. Uppuluri VS, Bakis CE, Nanni A, Boothby TE (1996) Analysis of the bond mechanism in FRP reinforcement bars: the effect of bar design and properties. Proceedings of the Second International Conference on Advanced Composite Materials in Bridges and Structures (ACMBS-II), Montreal, Canada. pp. 893900

20. Gao D, Benmokrane B, Tighiouart B (1998) Bond Properties of FRP rebars to concrete. Technical Report, Department of Civil Engineering, University of Sherbrooke, Sherbrooke, Quebec, Canada. pp. 27.

21. Hassan T, Rizkalla S (2003) Investigation of bond in concrete structures strengthened with near surface carbon fiber reinforced polymer. J Compos Constr 7: 248-257.

22. Islam AKMA (2009) Effects of NSM CFRP bars in shear strengthening of concrete members. ASCE American Society of Civil Engineers, Structures Congress. pp. 1-14.

23. Bousselham A, Chaallal O (2004) Shear strengthening reinforced concrete beams with fiber-reinforced polymer: Assessment of influencing parameters and required research. Aci Struct J 101:219-227. 